\title{
On the Way to the Multilingual Dictionary of Proverbs: Sociolinguistic Experiment and Internet Resources
}

\author{
Marina Yu. Kotova, Olga V. Raina, Olesya S. Sergienko \\ Faculty of Philology \\ St. Petersburg State University \\ St. Petersburg, Russian Federation \\ e-mail: m.kotova@spbu.ru; o.raina@ spbu.ru; o.sergienko@spbu.ru
}

\begin{abstract}
The method of one sociolinguistic paremiological experiment used in this research opens new innovative ways to determine a proverbial invariant in a reflection of Russian paremiological minimum in Slavic languages. In order to solve the problem of the invariant identification, the authors applied 2 criteria: the maximum number of respondents, who used this variant, and the confirmation of its usage with a context from the Internet sources.
\end{abstract}

Keywords - dictionary of proverbs, paremiological minimum, Czech, Polish, Slovak, sociolinguistic experiment, invariant

\section{INTRODUCTION}

Our basic sociolinguistic paremiological research was fulfilled in 2003-2004 in collaboration with the colleagues from the six Slavic countries: from Byelorussia, Bulgaria, the Czech Republic, Poland, Serbia, Slovakia. Later the paremiological group at the Department of Slavonic Philology of Saint Petersburg State University confirmed the results of that experiment partly in 2011-2013 (for Bulgarian and Czech), partly in 2014-2017 (for Slovak, Byelorussian and Polish).

In our earlier research in 2004 on the basis of 100 questionnaires for each language from the six mentioned above (600 questionnaires in total), which were filled by 100 Byelorussian, 100 Bulgarian, 100 Czech, 100 Polish, 100 Serbian and 100 Slovak respondents (mainly students, nativespeakers) we prepared the six summary lists of proverbs with all the variants, written by our respondents. Ten years later, in 2011-2017, we filtered these summary lists through Internet search and found out some current contexts as actualization of the proverbs from our general lists. Three handbooks with the results of this Internet survey - Bulgarian, Czech and Slovak have been published for our University students' seminar of Slavonic Paremiology for MA in Slavistics as supplements to our earlier multilingual dictionary of Slavic proverbs with English parallels [1]. The Czech handbook received a positive review in one of the leading Czech philological journals [2]. Next handbook - Byelorussian - is on its way to be prepared for release.

Thus, only 'alive' Slavic proverbs have been chosen for analysis here in full accordance with our earlier works and dissertation theses [3]. Our sociolinguistic paremiological experiment from the year 2003-2004 was based on the theory of G.L. Permiakov's paremiological minimum [4], also supported by European scholars [5].

Let us see in detail and attempt to analyze this process and paremiographic significance of our paremiological sociolinguistic experiment in Czechia, Poland and Slovakia from the point of view of identification of proverbial invariant in our Czech, Polish and Slovak material.

\section{CZECH PROVERBS}

G.L. Permiakov's theory of paremiological minimum has generated some very interesting research in paremiology and paremiography in Czech Republic (works by F. Cermak, E. Mrhacova, F Schindler and others) [6]. F. Cermak in his research of the Czech paremiological minimum on the basis of the Czech National Corpus (CNC) from 2003 mentions that the very existence of proverb variants is supported and enabled by absence of any codification or artificial petrification of proverbs, which seem to live a life of their own [7].

G.L. Permiakov called an 'invariant' the very situation that was determined by a proverb, i.e. it's meaning, the constant and stable essence that belongs to all the proverbs with the same meaning - those G.L. Permiakov called 'variants' [8]. In our research we shall consider as an 'invariant' the form of the proverb with the highest frequency of usage among our respondents, regardless of whether it coincides with the traditional dictionary form or not. For our research it is significant that the proverbs were given in the questionnaires without any contexts, so that the respondents could complete them in the form that they remembered. It allowed us to distinguish only 'alive' Czech proverbs for the future Multilingual dictionary of proverbs

The analysis of the 100 Czech questionnaires showed that only 15 proverbs were completed by all Czech respondents in one and the only variant/form, e.g., Co na srdci, to na jazyku (96 resp.); Kdo pozdě chodí, sám sobě škodí (96 resp.); Tichá voda břehy mele (99 resp.); Zdání klame (88 resp.) and others. In all of the above cases the form used by all the respondents matched completely with the form in which a proverb was 
originally derived from a paremilogical dictionary. However out of the total number of analyzed proverbs these invariable cases constitute only around $3 \%$.

The rest of the proverbs were continued by our respondents in more than one variant. As mentioned earlier, our goal was to determine the invariant, and it was an easy task when one variant in the respondents' answers absolutely prevailed over the others, e.g., Zed' hlavou neprorazís (82 resp.) / Zed' hlavou nerozbiješ (4 resp.) / Zed' hlavou neprobořiž (2 resp.) / Zed' hlavou nerozbořišs (2 resp.) / Zed' hlavou neprozradišs (1 resp.).

Some proverbs may have just a few variants, for others the number of variants may reach up to 15,20 or even 25 . For example, 94 Czech respondents continued the proverb Kdy nejde hora $\boldsymbol{k}$ Mohamedovi, musí Mohamed $\boldsymbol{k}$ hoře in 15 different forms - all of them having the same meaning. Here are just two of them: Když nejde hora $k$ Mohamedovi, musí Mohamed $k$ hoře (45 resp.); Když nejde Mohamed k hoře, musí hora $k$ Mohamedovi (4 resp.), etc. Among the variants, those that were pointed out by more than 4 respondents found the proof of their usage in various Internet sources, e.g.,

$V$ létě je jejich obživou produkce vina, které v běžném obchodě nekoupite, protože se distribuje jen ve velmi malém množství. A když nejde hora $k$ Mohamedovi, musi jit Mohamed $k$ hoře. I vy tak musite prijet na Paxos, abyste lahodné víno ochutnali (http://recko.travelon.cz).

It is obvious that the longer the proverb is the more variants it has. R. Blatna points out that perhaps in the first place language speakers remember the main semantic structure of a proverb, not certain lexical components. This is how the synonymic rows appear [9]. But the core, the basis of the proverb and its meaning in most cases remains unvaried.

In all the examples given above we can talk about 'usual' variability which is an integral part of the national paremiological corpus and just slightly deviates from the norm (i.e. invariant) in its lexical or grammatical form.

Other examples represent individual occasional variants used by respondents in two cases - either they didn't know the proverb and just made it up, or it was an intended distortion of a proverb. Such occasional variability and creative approach were very typical for this paremiological experiment, e.g., $\boldsymbol{B} \boldsymbol{e z}$ práce nejsou koláče (99 resp.) / Bez práce nejsou holiče (1 resp.).

We have analyzed some of the cases when a proverb invariant was quite definite due to respondents' unanimity. However, an invariant is not so obvious when the respondents point out two endings with similar frequency: Darovanému koni na zuby nehled' (48 resp.) / Darovanému koni na zuby nekoukej (49 resp.).

Most interesting is that in the dictionary „Ceska prislovi" this proverb is given in the same form as it was recorded by F.L. Celakovsky - Darovanému koni na zuby se nedivej. But the paremiological experiment proved that this form is currently familiar to just $3 \%$ of respondents while most language speakers today prefer more colloquial variants $-n a$ zuby nehled' and na zuby nekoukej. This has also been proved by numerous Internet contexts. It is obvious that both variants must be reflected in the modern paremiological dictionaries, as we find in F. Cermak's latest edition [10].

A popular tendency in modern Czech language is the high frequency of proverbs' reduced variants which often become invariants, e.g., Lež má krátké nohy (95 resp.) / Lež má krátké nohy, daleko neujde (2 resp.).

\section{POLISH PROVERBS}

The tradition of proverbial dictionaries on Polish material was started many centuries ago by the dictionary of G. Knapski [11]. In the XX-XXI centuries it was continued in Poland on the wave of the paremiographic rise by the dictionaries of $D$. and A. Świerczyńscy [12].

Bilingual proverbial dictionaries with Russian, Polish and German material are represented by the Russian-Polish and Polish-Russian dictionaries of R. Stypuła [13], German-Polish and Polish-German dictionary of A. Wójcik and H. Ziebart [14].

In 2014 the multilingual dictionary of $\mathrm{H}$. Walter, V. Mokienko, E. Komorowska, K. Kusal was published in which Russian proverbs are presented simultaneously with their German and Polish proverbial parallels [15]. The main criterion for the selection of the material was the use of units in the works of Russian writers of the XIX-XXI centuries, as well as the regularity of their appearances in fiction and journalism. The frequency of the use of proverbs was experimentally adjusted by the results of the questionnaire survey of students. 630 Russian, 1825 German and 1990 Polish proverbs were included in the dictionary. The authors of the dictionary gave the definition of proverbs, classified them according to the frequency of usage in all three languages, showed the variability in use, gave a historical and cultural commentary, and pointed out the German and Polish proverbial parallels to each proverb. The subjective-author's method was used in order to find out active proverbs.

For our research Polish proverbs were identified through computer processing of the questionnaires of Polish respondents of the sociolinguistic paremiological experiment, which was held in 2003 at the universities of Poland.

34 proverbs were completed by the only one variant, e.g., Głodnemu chleb na myśli (93 resp.), Jakie pytanie, taka odpowiedź (98 resp.), Kto się czubi, ten się lubi (98 resp.), Lepiej późno, niż wcale (98 resp.), Nie ma dymu bez ognia (89 resp.), Niedaleko pada jabłko od jabłoni (95 resp.), Pieniądze szczęścia nie daja (96 resp.), Pierwsze koty za płoty (97 resp.), Pożyjemy - zobaczymy (95 resp.), Prawda w oczy kole (93 resp.), Prawdziwych przyjaciót poznajemy $w$ biedzie (96 resp.), Raz kozie śmierć (90 resp.), Stuchaj uchem, a nie brzuchem $(90$ resp.), Ściany maja uszy (95 resp.), Wiele hałasu o nic (89 resp.), Wszyscy za jednego, jeden za wszystkich (83 resp.), Złość piękności szkodzi (94 resp.).

A lot of proverbs have several variants with different lexical components, e.g., Co ma być, będzie (1 resp.) / Co ma być, nie ucieknie (1 resp.) / Co ma być, to będzie (92 resp.) / Co ma być, to i będzie (1 resp.); Gdzie kucharek sześć, nie ma co jeść (1 resp.) / Gdzie kucharek sześć, tam cycków dwanaście (1 
resp.) / Gdzie kucharek sześć, tam nie ma co jeść (95 resp.) / Gdzie kucharek sześć, tam nie ma gdzie jeść (1 resp.); W zdrowym ciele młody duch (3 resp.) / W zdrowym ciele zdrowy duch (89 resp.), so we determined the invariant due to the number of respondents that continued the proverb.

Apetyt rośnie (wzrasta) w miare (1 resp.) - No illustrations in the Internet.

Apetyt rośnie (wzrasta) miare jedzenia (97 resp.) - $\underline{\text { Apetyt }}$ rośnie $w$ miare jedzenia. Ja $w$ swoim pokoju $12 \mathrm{~m}^{2}$ mam Samsunga 32". Na poczatku bytem w totalnym szoku, że ojej ojojoj - jakie to duze i fajne. Teraz stwierdzam, że przydałyby się 42" - tylko szafa już nie pomieści (http://twojepc.pl).

Apetyt rośnie (wzrasta) wraz z jedzeniem (1 resp.) - No illustrations in the Internet.

There were also a lot of grammatical variants of proverbs, e.g., Szewc bez butów chodzi (82 resp.) / Szewc bez butów chodzit (1 resp.); Syty głodnego nie rozumie (10 resp.) / Syty glodnego nie zrozumie (83 resp.). The variant with more frequency was recognized as invariant.

We identify the variant of the proverb that has Internet illustrations as invariant, even if it was pointed out by fewer respondents, e.g.,

Kto pod kim dotki kopie, sam w nie wpada (20 resp.) - Od tej pory dziewczyny zostały najlepszymi przyjaciółkami. Reszte obozu wszyscy spędziliw zgodzie i przyjaźni. Wniosek z tego taki, że „kto pod kim dołki kopie, sam w nie wpada”. Trzeba pamiętać też, że „nie powinno oceniać książki po okładzie” (http://bryk.pl).

Kto pod kim dolki kopie, sam w nie wpada potem (1 resp.) / Kto pod kim dotki kopie, ten sam do nich wpada (1 resp.) / Kto pod kim dotki kopie, ten sam pod nie wpada (1 resp.) / Kto pod kim dołki kopie, ten sam w nie pada (1 resp.) / Kto pod kim dotki kopie, ten sam w niej wpada (1 resp.) / Kto pod kim dotki kopie, ten $w$ nie wpada (1 resp.) - No illustrations in the Internet.

Kto pod kim dolki kopie, ten sam w nie wpada (82 resp.) „Kto pod kim dotki kopie, ten sam $w$ nie wpada”. To stare przystowie bardzo dobrze pasuje do tej gry. A czemu? Zaraz, się dowiecie (http://www.nes.e9.pl).

The studies of the reflection of the Russian paremiological minimum in the Polish language are of great interest. All the results of our paremiological sociolinguistic experiment in Poland will be reflected in the upcoming in SPbSU Polish "Tetradi paremiographa. Vypusk 5" (Handbooks of a paremiographer. Issue 5).

\section{SLOVAK PROVERBS}

At the beginning of our century a Slovak scholar Peter Durčo supported the theory of paremiological minimum of G.L. Permiakov with his own paremiological sociolinguistic experiment held by technical means of the Internet. The results of the 12 questionnaires filled by 12 Slovak respondents were then published in Slovakia in 2002 [16].
The principles of the sociolinguistic paremiological experiment are also widely used in the scientific research of Slovak paremiologist Dana Balakova [17].

The G.L. Permiakov's idea of paremiological minimum inspired the authors of the new version of fundamental Zaturecky's Slovak proverbs' dictionary (1897) prepared by Zuzana Profantova and Jozef Mlacek (1996) [18]. The coauthors of this dictionary were its only respondents, and according to their own paremiological background they have selected the Slovak proverbs from Zaturecky's dictionary for a new edition. J. Mlacek evaluated in details the outstanding role of A.P. Zaturecky in the development of Slovak paremiography in his studies published in 1997 and 2013 [19].

Our first Slovak paremiological questionnaires were filled with the Slovak respondents in Slovakia by our student and assistant Olga Petrova [20]. The 100 Slovak native-speakers participated in our sociolinguistic paremiological experiment in Bratislava and other Slovak areas in 2003-2004 (sic $60 \%$ female, $40 \%$ male, from 17 up to 76 years old, about $60 \%$ of them were students). The paremiological questionnaire consisted of 568 Slovak proverbs (of their beginnings). At the end of the experiment we had to collaborate with a great number of variants of the final part of each proverb, pointed out by our respondents. This tremendous work was held by the authors of this article and our doctoral student Olga Tararaeva in her MA thesis [21].

One of the aims of this experiment was to determine the 'alive' invariant of each proverb. We conducted then the next experiment by Internet search of the variants and made up our mind about the invariant only if found out the confirmation of existence of the variants in the contexts of Internet discourse.

Let us see a few typical situations (or problems) that we have faced during this process of identification of Slovak proverbial invariants:

1) A single variant (with no doubts - an invariant) is written in all questionnaires, e.g., Aj steny majú uši (97 resp.) - (Ne)dôverujte. Aj steny majú uši, no pozor by ste si mali dávat' vždy predovšetkým na l'udí. Nikdy nebud'te $k$ nikomu na sto percent úprimný, pretože $v$ práci ste vždy $v$ pozícii potenciálnych konkurentov (http://magazin.atlas.sk).

2) From 2 (or more) lexical variants we recognize as an invariant the variant with more frequency (e.g., Príležitost' robi zlodeja in the proverb below):

Príležitost' robí človeka (2 resp.) - Hovorí sa, že príležitost' robi človeka. Viem byt' verný vo svojich povinnostiach aj vtedy, ked' ma nikto nekontroluje (http://www.srdcepastiera.sk).

Príležitost' robí šance (1 resp.) - No illustrations in the Internet.

Príležitost’ robí zlodeja (60 resp.) - Hovorí sa síce, že príležitost' robí zlodeja, mne sa však zdá, že príležitost' zlodeja nerobí, iba zlodeja odkryje (http://www.postoy.sk).

3) An invariant between grammatical variants is recognized also according to the top frequency, e.g., 
Opakovanie je matka múdrosti (66 resp.) - 'Opakovanie je matka múdrosti' je vel'mi praktické porekadlo do života a moja triedna učitel'ka, neustále ho opakujúc, asi nevedela, že cituje Bibliu: "Jehovova pripomienka (opakovanie) je dôveryhodná, robí neskúseného múdrym." - Žalm 19:7 (https://luzinsky.blog.sme.sk).

Opakovanie je matkou múdrosti (28 resp.) - Opakovanie je matkou múdrosti. Nie je to inak ani pri osvojovaní si cudzieho jazyka. Táto metóda fakt potreby opakovat' nezanedbáva a učivá častejšie opakuje (http://intellego.sk).

4) If there are no Internet illustrations for all the variants of the proverb on our list, we do not consider it as a potential paremiological unit of our future dictionary of current proverbs.

\section{CONCLUSION}

The sociolinguistic paremiological experiment conducted for several Slavic languages in 2003-2004 continues to be relevant and still provides a lot of opportunities for scientific research. Supported by the results of a large-scale Internet search that proved the high frequency of all the identified invariants, it is now ready to contribute to a new edition of multilingual Russian-Slavic dictionary of proverbs (with English parallels) which the authors of this article hope to accomplish in the near future.

\section{REFERENCES}

[1] Kotova M. Yu. Russko-slavjanskij slovar poslovits s anglijskimi sootvetstvijami / Pod red. P. A. Dmitrieva. - SPb.: Izd-vo S.-Peterb. Un-ta, 2000. - 360 p.; Kotova M. Yu., Raina O. V., Kolpakova A. A. Tetradi paremiographa. Vypusk 1: Bolgarskie poslovichnyje paralleli russkih poslovits paremiologicheskogo minimuma / Pod redaktsijej M. Yu. Kotovoj. - SPb., 2013. - 240 p.; Kotova M. Yu., Sergienko O. S. Tetradi paremiographa. Vypusk 2: Czeshskie poslovichnyje paralleli russkih poslovits paremiologicheskogo minimuma / Pod redaktsijej M. Yu. Kotovoj. - SPb., 2013. - 278 p.; Kotova M. Yu., Sergienko O. S., Tararaeva O. N. Tetradi paremiographa. Vypusk 3: Slovatskie poslovichnyje paralleli russkih poslovits paremiologicheskogo minimuma / Pod redaktsijej M. Yu. Kotovoj. - SPb., 2017. - 286 p.

[2] Lepilová K. "Tetradi paremiografa” petrohradských bohemistů // Opera Slavica 2013, vol. 23, issue 4. P. 61 - 62. Paralleli russkih poslovits paremiologicheskogo minimuma / Pod redaktsijej M. Yu. Kotovoj. SPb., 2013. $-240 \mathrm{p}$.

[3] Kotova M. Yu. Lektsii po sopostavitelnoj slavjanskoj paremiologii. SPb.: Filologicheskij fakultet SPbGU, 2010. - 170 p.; Raina O. V. Polskaja dialektnaja paremiologia: Na materiale guralskogo dialekta. SPb., 2011. - 64 p.; Sergienko O. S. Normativnost' i variantnost' czeshskih i slovatskih poslovits. - SPb.: Izd-vo S.-Peterb. Un-ta, 2015. $296 \mathrm{p}$.
[4] Permiakov G. L. Osnovy strukturnoj paremiologii. - M.: Nauka, 1988. $236 \mathrm{p}$.

[5] Bittnerová D., Schindler F.: Česká př́isloví. Soudobý stav konce 20. století. - Praha: Karolinum 1997. - 315 p.

[6] Čermák F. Základní slovník českých př́sloví. - Praha: Lidové Noviny, 2013. - 136 p.; Mrhačová E. a kol. Západoslovanské paremiologické dědictví. - Ostrava: Filozofická fakulta Ostravské univerzity v Ostravě, 2010. - 278 p.; Schindler F. Sprichwort im heutigen Tschechischen: empirische Untersuchungen und semantische Beschreibung. - München: Otto Sagner, 1993. $-572 \mathrm{p}$.

[7] Čermák F. Paremiological Minimum of Czech: The Corpus Evidence. // H. Burger, A. Häcki Bufofer, G. Greciano (Eds.): Flut von Texten Vielvalt der Kulturen. Ascona 2001 zur Methodologie und Kulturspezifik der Phraseologie, Hohengehren: Schneider Verlag, 2003. - P. 15-31.

[8] Permiakov G. L. Poslovitsy i pogovorki narodov vostoka. - M.: Labirint, 2001. $-624 \mathrm{p}$.

[9] Blatná R. Czech proverbs vanishing in the black hole. Elaborated on the material of the Czech National Corpus // Europhras' 97. Phraseology and Paremiology. - Bratislava: Akademia PZ, 1998. - P. 24-29.

[10] Čermák F. Slovník české frazeologie a idiomatiky 4 - Výrazy větné. Praha: LEDA, 2009. - $1267 \mathrm{p}$.

[11] Cnapius G. Adagia Polonica. - Cracoviae, 1632. - 1059 p.

[12] Świerczyńska D., Świerczyński A. Przysłowia w sześciu językach. Warszawa: Wydawnictwo Naukowe PWN, 1996. - 327 p.; Świerczyńska D., Świerczyński A. Słownik przysłów w ośmiu językach. - Warszawa: Wydawnictwo Naukowe PWN, 2001. - 437 p.

[13] Stypuła R. Słownik przysłów i powiedzeń rosyjsko-polski; polskorosyjski. - Warszawa: Wiedza Powszechna, 2003. - 999 p.

[14] Wójcik A., Ziebart H.: Słownik przysłów niemecko-polski, polskoniemecki. - Warszawa: Wiedza Powszechna, 2001. - 547 p.

[15] Walter H., Mokienko V., Komorowska E., Kusal K. Russko-nemeckopolskij slovar aktivnyh poslovits (s inojazychnymi paralleljami i istoriko-kulturologicheskimi kommentarijami).. Greifswald - Szczecin, 2014. $-433 \mathrm{p}$.

[16] Ďurčo P. K výskumu súčasnej živej slovenskej paremiologie // Studia Academica Slovaca 31: Prednášky XXXVIII. Letnej školy slovenského jazyka a kultúry. - Bratislava: Stimul, 2002. - P. 51-60.

[17] Baláková D. Biblická frazeologia v podvedomí slovenskej, ruskej a nemeckej mladej generácie // Slavyanskaja frazeologija i Biblija. Greifswald - Sankt-Petersburg - Ružomberok, 2013. - P. 22-30.

[18] Záturecký A. P. Slovenské príslovia, porekadlá a úslovia. Bratislava, 1975 (1st edition in 1897, Prague); Slovenské príslovia a porekadlá: Výber zo zbierky A. P. Zátureckého: Zv. 1 - 2 / Výber a zost. J. Mlacek, Z. Profantová. - Bratislava, 1996. - 320 p.

[19] Mlacek J. Príspevky k jazykovej charakteristike Slovenských prísloví, porekadiel a úsloví A.P. Zátureckého. - Bratislava: Stimul, 1997. - P. 229-268.

[20] Petrova O. A. Slovatskie poslovitsy na materiale sociolingvisticheskogo experimenta i gazetnogo texta // V Slavisticheskie chtenia pamjati prof. P. A. Dmitrieva i prof. G. I. Safronova. SPb., 2004. - P. 63-66.

[21] Tararaeva O. N. Tipy preobrazovanij slovatskih, czeshskih i anglijskih poslovits $\mathrm{v}$ Internet-prostranstve. Vypusknaja kvalifikatsionnaja rabota magistra filologii SPbGU. - SPb., 2016. - 171 p. 